\title{
Assessing Morphological Traits Variation and Fruit Production of Lophira lanceolata (Ochnaceae) in Benin
}

\author{
Aliou Dicko ${ }^{1 *}$, Armand Kuyéma Natta ${ }^{1,2}$, Honoré Samadori S. Biaou ${ }^{1,2}$, Arcadius Akossou² \\ ${ }^{1}$ Laboratory of Ecology, Botany and Plant Biology (LEB), Parakou, Benin \\ ${ }^{2}$ Faculty of Agronomy, University of Parakou (UP), Parakou, Benin \\ Email: *dicko_aliou@yahoo.fr
}

How to cite this paper: Dicko, A., Natta, A.K., Biaou, H.S.S. and Akossou, A. (2019) Assessing Morphological Traits Variation and Fruit Production of Lophira lanceolata (Ochnaceae) in Benin. American Journal of Plant Sciences, 10, 1048-1060.

https://doi.org/10.4236/ajps.2019.106076

Received: April 25, 2019

Accepted: June 22, 2019

Published: June 25, 2019

Copyright $\odot 2019$ by author(s) and Scientific Research Publishing Inc. This work is licensed under the Creative Commons Attribution International License (CC BY 4.0).

http://creativecommons.org/licenses/by/4.0/

(c) (i) Open Access

\begin{abstract}
Lophira lanceolata is an oleaginous tree species whose fruit is used for vegetable oil production in Benin. The present study highlighted the fruit production and characterization of the morphological traits of the fruits and seeds of this species. A total of 196 mature trees in production were randomly sampled in Borgou-Nord, Borgou-Sud and Atacora Chain phytodistricts. Descriptors were characterized globally at the level of phytodistricts surveyed. Pearson correlation test stands out the relationships between the different descriptors. The effect of phytodistricts on fruit production was analyzed using a Generalized Linear Model (GLM) and the variation of morphological traits between phytodistricts was examined through Kruskal-Wallis test. Finally, SMA regression was used to test the influence of the phytodistrict on the relationship between $L$. lanceolata seed and fruit weight. This study revealed that there is a positive and significant correlation between the morphological traits of fruits and those of seeds. Trees descriptors (e.g. total height, diameter at breast height, and leaf petiole length) predict fruit production of L. lanceolata, but are not significantly correlated with fruit and seed traits. In the Atacora Chain phytodistrict, breeding trees are entering production with small diameter, low height and produce little number of fruits per tree with higher weight, unlike the Borgou-Nord and Borgou-Sud phytodistricts. These results can be useful in the selection of early breeding tree in Atacora Chain phytodistrict and high-yielding trees from individuals in the Borgou-Nord and Borgou-Sud phytodistricts.
\end{abstract}

\section{Keywords}

False Shea, Phenotypic Traits, Fruit Production, Phytodistricts, Conservation 


\section{Introduction}

The West African savannas are a reservoir of highly diversified plant species whose products are very useful for population's survival [1]. The exploitation of non-timber forest products and services from savannas is not only widespread [2], but plays medicinal, cultural, nutritional and economic roles [3]. Some species remain underutilized due to the lack of knowledge [4], whereas the majority of savanna-zone plant species are under high pressure due to human activities and demography [5]. One of the disadvantages of ecosystem degradation in recent decades has been the loss of natural regeneration for many species [6]. The drastic decline in crop production and the loss of genetic diversity are the real risks to be observed in the long term [7]. To mitigate these risks, it is necessary to define policies to protect, domesticate, extend and enhance the potential of species for the benefit of local populations [8]. The domestication process is still based on the selection of desirable genes [9], given indigenous knowledge of target species [10]. Moreover, within climatic zones, environmental conditions are known to induce a large spatial variability in the morphology and productivity of fruit trees [11]. Precipitation, relative humidity, and temperature can cause significant variations in the morphological characteristics of species populations [9]. In the context of climate change, trees could express new potentialities in response to bioclimatic factors. Consequently, studies on the ecological adaptation of fruit trees along the climatic gradient are important for predicting their productivity in the future [12]. Variability studies are needed to increase plant productivity and also for future breeding work [13]. Morphological descriptors are the basis for the characterization of plant genotypes on the basis of their phenotype [14].

Despite the benefits and growing interest in the domestication of wild fruit trees, knowledge of these trees is still limited [15]. It is the case of Lophira lanceolata Tiegh. ex Keay (Ochnaceae), a mesophanerophyte of the Sudano-Guinean and Sudanian savannahs whose multiplicity of social uses accentuates anthropic pressures on its populations in Benin [16]. This indigenous species is known for its food, culinary, agricultural, pastoral, veterinary, domestic, artisanal, industrial and medicinal uses [17]. The oil extracted from the seeds is used in human food, in cosmetics and in the preparation of traditional soaps [17]. Despite its great potential to contribute to the reduction of rural poverty in Benin [18] and the growing interest for its fruits producing oil with very high nutritional value [19], data on fruit production from wild populations along a climatic gradient remain unknown, as can variables predicting this production. The present study aims to elucidate variations in fruit production and morphological traits of fruits and seeds of $L$. lanceolata in Benin. Specifically, we will: 1) Determine the relationship between tree and fruit characteristics of $L$. lanceolata, 2) Test the effect of phytodistricts difference on $L$. lanceolata morphological traits and fruit production, 3) Determine the relationship between $L$. lanceolata fruit mass and its seed mass according to the phytodistricts in Benin. 


\section{Material and Methods}

\subsection{Study Species}

Lophira lanceolata, also named the ironwood or the false shea is a tree species that may reach $16(-24) \mathrm{m}$ tall [20]. Its Flowers are bisexual, regular and white in color. Leaves are simple, entire, and alternate but clustered at the end of branches. Its inflorescence is a terminal, pyramidal, lax panicle with 15 to $20 \mathrm{~cm}$ long. Fruits are assimilated to conical shape. Seed are ovoid in shape, chestnut-colored and glabrous [20].

\subsection{Study Area}

This study was carried out in three phytodistricts [21], two of which are located in the Sudanian zone (Borgou-Nord and Atacora Chain) and one in the Sudano-Guinean zone (Borgou-Sud) (Figure 1). The choice of the study area is motivated by the frequency and abundance of productive tree of $L$. lanceolata.

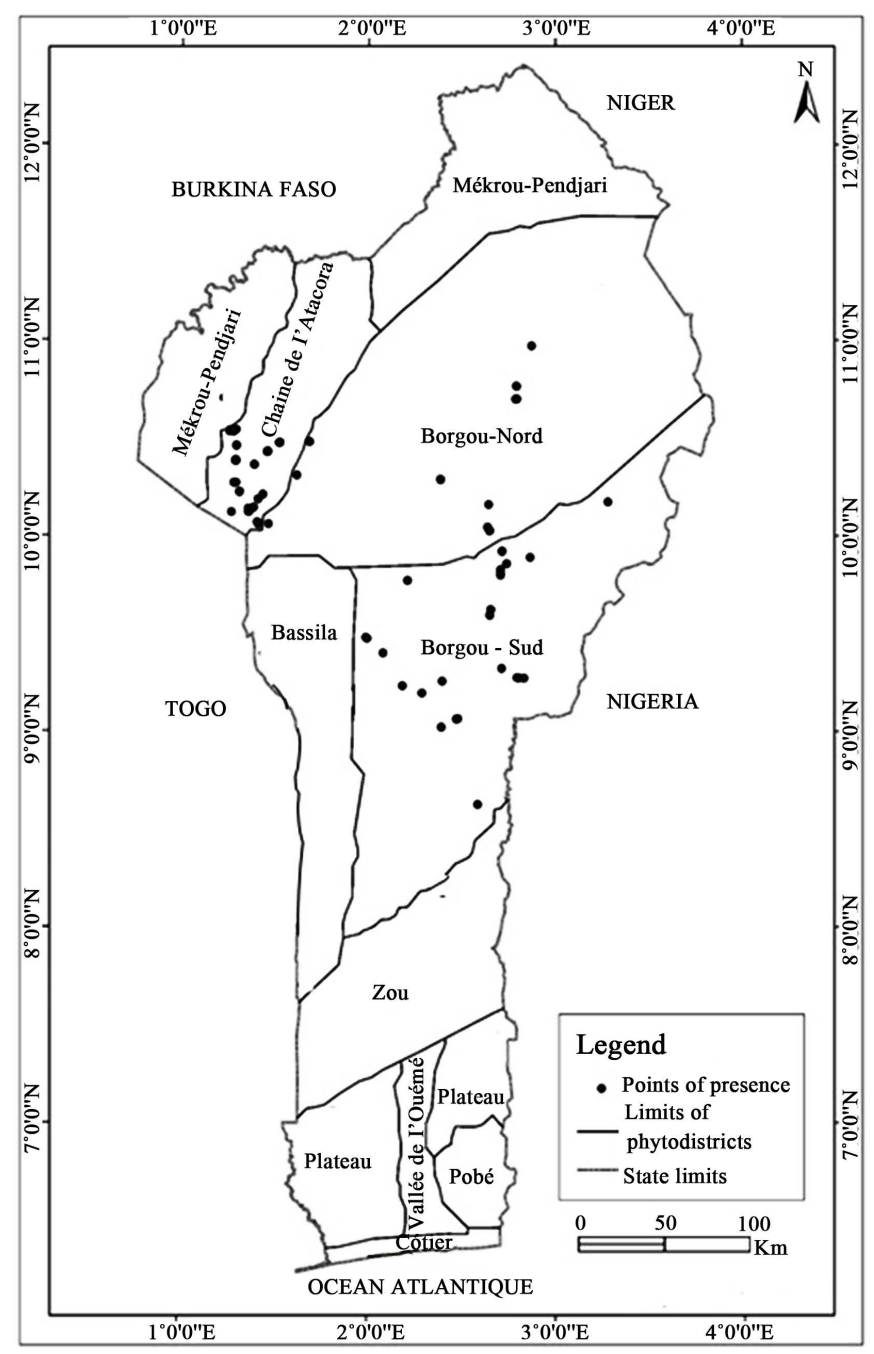

Figure 1. Points of presence of breeding Lophira lanceolata trees sampled in central and northern Benin. 


\subsection{Data Collection}

Data were collected from 196 randomly selected productive trees in three (03) phytodistricts (Borgou-Nord, Borgou-Sud, Atacora Chain). On each productive tree, the diameter at breast height ( $\mathrm{dbh}$ ) and the total height were measured. At physiological maturity, all the fruits were collected from each tree, counted and weighed. For each tree, 30 fruits were randomly selected and the following variables were measured: the large sepal length, the large sepal width, the small sepal length, the small sepal width, the fruit length, the fruit diameter, the seed length, the seed diameter, the fruit weight and the seed weight. Thirty (30) leaves were then taken from each tree and the variables (petiole length, limb diameter, limb length) were measured on each leaf. The different descriptors were analyzed overall on all the phytodistricts of the study area thanks to a descriptive statistic (average, standard deviation, coefficient of variation, maximum, minimum). The coefficient of variation is higher in the number of fruits per tree (CV $=210.81)$ while it is lower in the large sepal length $(\mathrm{CV}=11.84)($ Table 1$)$.

\subsection{Data Analysis}

The relationships between the descriptors were analyzed by submitting a data

Table 1. Lophira lanceolata descriptors characteristics.

\begin{tabular}{cccccc}
\hline Variables & Mean & Standard deviation & Coefficient of variation & Minimum & Maximum \\
\hline $\mathrm{Ht}$ & 8.513 & 0.168 & 27.67 & 4 & 16 \\
$\mathrm{dbh}$ & 22.714 & 0.621 & 38.29 & 7.9 & 58.2 \\
$\mathrm{Dlimb}$ & 4.5467 & 0.0578 & 17.79 & 2.7 & 7.1 \\
Sfo & 105.6 & 2.31 & 30.64 & 40.7 & 209.5 \\
LongP & 2.9015 & 0.0601 & 28.98 & 1.2 & 5.6 \\
PFr (g) & 1.149 & 0.0144 & 17.6 & 0.6 & 1.6 \\
LongGS & 7.8039 & 0.066 & 11.84 & 2.8 & 10.1 \\
LargGS & 2.3265 & 0.049 & 29.48 & 0.4 & 3.9 \\
LongPS & 3.1944 & 0.0527 & 23.11 & 1.4 & 5.6 \\
LargPS & 0.8558 & 0.019 & 31.09 & 0.2 & 1.5 \\
LongFr & 2.7746 & 0.025 & 12.59 & 1.7 & 3.6 \\
DFr & 1.2004 & 0.0143 & 16.67 & 0.7 & 1.9 \\
LongG & 2.2852 & 0.0385 & 23.58 & 0.9 & 3.3 \\
DGr & 0.9492 & 0.0168 & 24.83 & 0.4 & 2.0 \\
PGr & 0.8297 & 0.016 & 26.96 & 0.03 & 1.3 \\
NF/A & 1121 & 169 & 210.81 & 3 & 19825 \\
\hline
\end{tabular}

Note: $\mathrm{Ht}=$ total height $($ in $\mathrm{m}), \mathrm{dbh}=$ diameter at breast height $($ in $\mathrm{cm})$, LongP = petiole length (in $\mathrm{cm}$ ), Dlimb = limb diameter (in $\mathrm{cm}$ ), LongGS = large sepal length $($ in $\mathrm{cm})$, LargGS = large sepal width (in $\mathrm{cm}$ ), LongPS = small sepal length $($ in $\mathrm{cm}), \operatorname{LargPS}=$ small sepal width $($ in $\mathrm{cm})$, LongFr $=$ fruit length $($ in $\mathrm{cm}$ ), $\mathrm{DFr}=$ Fruit diameter $($ in $\mathrm{cm}$ ), LongG = seed length $($ in $\mathrm{cm}), \mathrm{DGr}=$ seed diameter $($ in $\mathrm{cm})$, Sfo $=$ leaf area (in $\mathrm{cm}^{2}$ ), $\mathrm{PFr}=$ fruit weight (in $\mathrm{g}$ ), $\mathrm{PGr}=$ seed weight (in $\mathrm{g}$ ); NF/A = number of fruits per tree. 
matrix of 16 variables (total height, dbh, petiole length, limb diameter, large sepal length, large sepal width, small sepal length, small sepal width, fruit length, fruit diameter, seed length, seed diameter, leaf area, fruit weight, seed weight, number of fruits produced) describing the morphology of the tree, fruits, seeds, leaves and the total production per tree $(\mathrm{N}=196$ productive trees).A GLM (Generalized Linear Model) was then performed with the negative binomial family to test the effect of phytodistricts on the number of fruits. This family was used to correct the overdispersion presented by the model. For continuous variables, Kruskal-Wallis test was performed because the conditions of normality and homogeneity of variance are not respected. In case of significant differences, pairwise comparison (two by two) was performed with the TukeyHSD test. Finally, an SMA (Standarded Major Axis) regression was performed with the sma function contained in the "smatr" package to test whether the phytodistrict influences the relationship between the weight of the fruit and the seed of L. lanceolata.

\section{Results}

\subsection{Relations between L. Ianceolata Descriptors}

There is a positive and significant correlation between several measured variables (Table 2). The length and width of the large sepal are positively correlated $(\mathrm{r}=0.53, \mathrm{p}<0.001)$. The large sepal length is correlated with the length and width of the small sepal $(r=0.34$ to $0.42, \mathrm{p}<0.001)$. In the same way, the large sepal width and that of the small sepal are positively related $(r=0.73, p<$ 0.001). The relationship between fruit and seed traits shows that fruit length and diameter are positively related to fruit weight $(\mathrm{r}=0.25$ to $0.26, \mathrm{p}<0.001)$. The length and diameter of the seed are all positively related to the seed weight $(r=$ 0.36 to $0.52, \mathrm{p}<0.001$ ) but only the seed length is positively related to the seed diameter $(r=0.44, \mathrm{p}<0.001)$. Similarly, there is a strong positive correlation between the morphological traits of the sepal and those of the fruit (Table 2). The length and width of both the small and large sepals are significantly related to the weight and length of the fruit $(r=0.21$ to $0.50, \mathrm{p}<0.01)$ to the weight and length of the seeds $(r=0.24$ to $0.49, \mathrm{p}<0.001)$. Only the length of the small sepal is not correlated with the length of the seeds and the weight of the fruit and the seed. The relationship between the morphological traits of the fruit and those of the seed shows that the length, diameter and weight of the fruit are all correlated with the weight of the seed $(r=0.23$ to $0.88, \mathrm{p}<0.001)$. The length and diameter of the fruit are also positively correlated with seed length and diameter $(r=0.32$ to $0.86, \mathrm{p}<0.001)$. Fruit weight is also correlated with seed length and diameter $(\mathrm{r}=0.27$ to $0.38, \mathrm{p}<0.001)$. Total height, $\mathrm{dbh}$, and petiole length are positively and significantly correlated with the total number of fruit per tree $(r=0.23$ to $0.25, \mathrm{p}<0.001)$.

There is no significant relationship between the total height and the fruit weight as well as that of the seed. It is the same for the relation between the dbh 


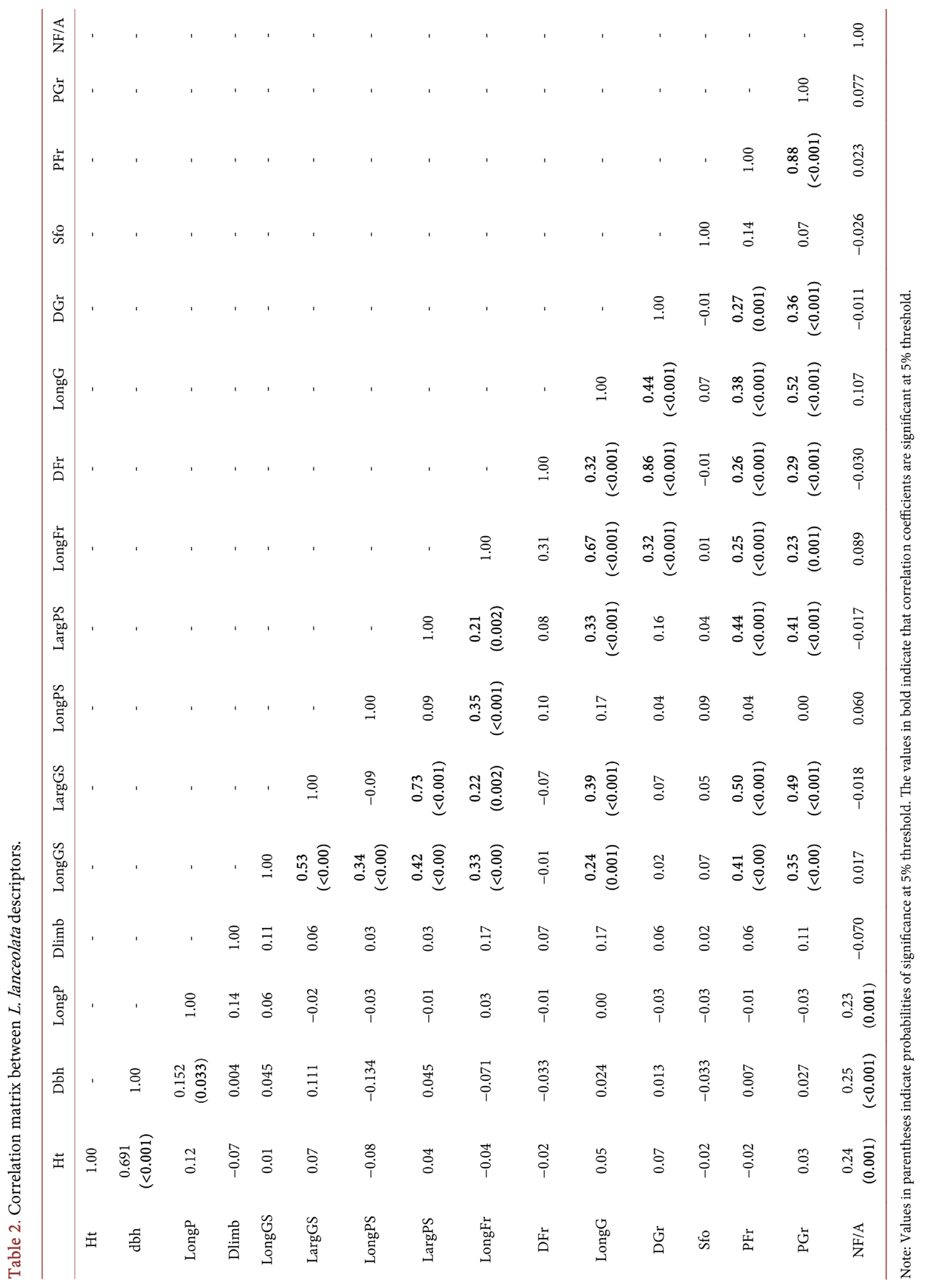


and the fruit weight or the seed weight. Similarly, the fruit weight is not related to the leaf area. But the fruit weight is positively and significantly correlated with the seed weight $(\mathrm{r}=0.88, \mathrm{p}<0.001)$.

\subsection{Descriptors Variation According to the Phytodistricts}

The results show that total height, dbh and fruit weight differ significantly between phytodistricts (Table 3 ). The populations of L. lanceolata from Borgou-Nord and those from Borgou-Sud show individuals of larger sizes, large diameters. Populations of the Atacora-Chain phytodistrict have fruits with a higher weight unlike fruits from populations of Borgou-Sud which are lighter.

Fruit production is significantly higher in Borgou-Nord than in the Borgou-Sud $(\mathrm{z}=-2.36, \mathrm{P}=0.0181)$ and the Atacora-Chain $(\mathrm{z}=-7.251, \mathrm{P}<0.001)$ (Table 4).

Table 3. Mean and standard deviation of L. lanceolata descriptors according to phytodistricts.

\begin{tabular}{cccccc}
\hline Variables & Borgou-Nord & Borgou-Sud & Atacora Chain & Statistics & P value \\
\hline Ht & $10.22 \pm 2.18 \mathrm{a}$ & $10.51 \pm 2.58 \mathrm{a}$ & $7.56 \pm 1.67 \mathrm{c}$ & $\mathrm{KW}=57.12$ & $<0.001$ \\
dbh & $27.40 \pm 6.37 \mathrm{a}$ & $28.71 \pm 10.39 \mathrm{a}$ & $19.97 \pm 7.29 \mathrm{c}$ & $\mathrm{KW}=40.26$ & 0.001 \\
LongP & $3.15 \pm 0.92 \mathrm{a}$ & $3.10 \pm 1.01 \mathrm{a}$ & $2.78 \pm 0.74 \mathrm{a}$ & $\mathrm{KW}=5.35$ & 0.07 \\
Dlimb & $0.20 \pm 0.18 \mathrm{a}$ & $0.13 \pm 0.12 \mathrm{a}$ & $0.17 \pm 0.12 \mathrm{a}$ & $\mathrm{KW}=2.61$ & 0.070 \\
LongGS & $7.83 \pm 0.97 \mathrm{a}$ & $7.52 \pm 1.09 \mathrm{a}$ & $7.87 \pm 0.85 \mathrm{a}$ & $\mathrm{KW}=3.51$ & 0.173 \\
LargGS & $2.46 \pm 0.69 \mathrm{a}$ & $2.07 \pm 0.68 \mathrm{a}$ & $2.36 \pm 0.67 \mathrm{a}$ & $\mathrm{KW}=4.37$ & 0.11 \\
LongPS & $3.03 \pm 0.67 \mathrm{a}$ & $3.28 \pm 0.67 \mathrm{a}$ & $3.21 \pm 0.76 \mathrm{a}$ & $\mathrm{KW}=1.68$ & 0.43 \\
LargPS & $0.87 \pm 0.24 \mathrm{a}$ & $0.81 \pm 0.23 \mathrm{a}$ & $0.86 \pm 0.28 \mathrm{a}$ & $\mathrm{KW}=1.16$ & 0.55 \\
LongFr & $2.77 \pm 0.38 \mathrm{a}$ & $2.66 \pm 0.30 \mathrm{a}$ & $2.80 \pm 0.35 \mathrm{a}$ & $\mathrm{KW}=6.21$ & 0.054 \\
DFr & $1.21 \pm 0.23 \mathrm{a}$ & $1.16 \pm 0.24 \mathrm{a}$ & $1.21 \pm 0.18 \mathrm{a}$ & $\mathrm{KW}=2.44$ & 0.295 \\
LongG & $2.30 \pm 0.61 \mathrm{a}$ & $2.12 \pm 0.52 \mathrm{a}$ & $2.32 \pm 0.52 \mathrm{a}$ & $\mathrm{KW}=4.76$ & 0.092 \\
DGr & $0.94 \pm 0.27 \mathrm{a}$ & $0.92 \pm 0.25 \mathrm{a}$ & $0.95 \pm 0.22 \mathrm{a}$ & $\mathrm{KW}=0.99$ & 0.609 \\
Sfo & $112.29 \pm 33.55 \mathrm{a}$ & $94.25 \pm 30.52 \mathrm{a}$ & $107.09 \pm 32.07 \mathrm{a}$ & $\mathrm{KW}=5.06$ & 0.08 \\
PFr & $1.14 \pm 0.21 \mathrm{ab}$ & $1.06 \pm 0.24 \mathrm{~b}$ & $1.17 \pm 0.18 \mathrm{a}$ & $\mathrm{KW}=6.67$ & $\mathbf{0 . 0 3}$ \\
\hline
\end{tabular}

The values bearing letters are mean \pm standard deviation. Those with the same letter on the same line are not significantly different at $5 \%$ threshold. $\mathrm{KW}=$ Kruskall-wallis statistic.

Table 4. Effect of phytodistricts on $L$. lanceolata fruit production.

\begin{tabular}{ccccc}
\hline & Estimate & Erreur standard & Valeur de $\mathrm{z}$ & $\operatorname{Pr}(>|\mathrm{z}|)$ \\
\hline (Intercept) & 8.0027 & 0.2056 & 38.92 & $<2 \mathrm{e}-16^{* * *}$ \\
District BS & -0.6578 & 0.2784 & -2.36 & $0.0181^{\star}$ \\
District CA & -1.6542 & 0.2281 & -7.251 & $4.13 \mathrm{e}-13^{* * *}$ \\
\hline
\end{tabular}

Note: $\mathrm{BS}=$ Borgou-Sud; CA = Atacora Chain; $\mathrm{BN}=$ Borgou-Nord (Reference modality), Pr = Probability; $\mathrm{z}$ $=$ Statistics associated with the GLM. 


\subsection{Effect of Phytodistricts on the Relationship between Seed Weight and Fruit Weight}

SMA regression showed a positive correlation between seed weight and fruit weight in the three phytodistricts ( $r=0.84$ to 0.94 , Figure 2$)$ and suggested that the weight of the seed increases with the weight of the fruit. However, the regression slopes vary significantly between phytodistricts and this suggests that for a fruit weight of less than $1.3 \mathrm{~g}$, the slope in Borgou-Nord is significantly higher than in the other two phytodistricts $(\mathrm{P}=0.01$, LRT $=8507)$. But there is no difference in slope between the Borgou-Nord and Atacora-Chain phytodistricts (Figure 2). The difference in slope suggests that the variability in seed weight associated with the increase of one unit of fruit weight is significantly higher in Borgou-Nord than in the other two phytodistricts. Thus, when the fruit weight increases by one gram, the seed weight increases by $1.29 \mathrm{~g}$ in Borgou-Nord while it increases by about $1 \mathrm{~g}$ in the other two phytodistricts.

\section{Discussion}

\subsection{Links within Morphological Traits and Fruit Production of L. lanceolata}

The morphological traits of fruits and seeds are positively and significantly correlated with one another, suggesting that fruit traits can be used as predictors of seed traits in the study area. These strong correlations indicate that the selection of indirectly measurable traits (seed length, seed diameter, seed weight) could be based on directly measurable traits (fruit length, fruit diameter, fruit weight), if

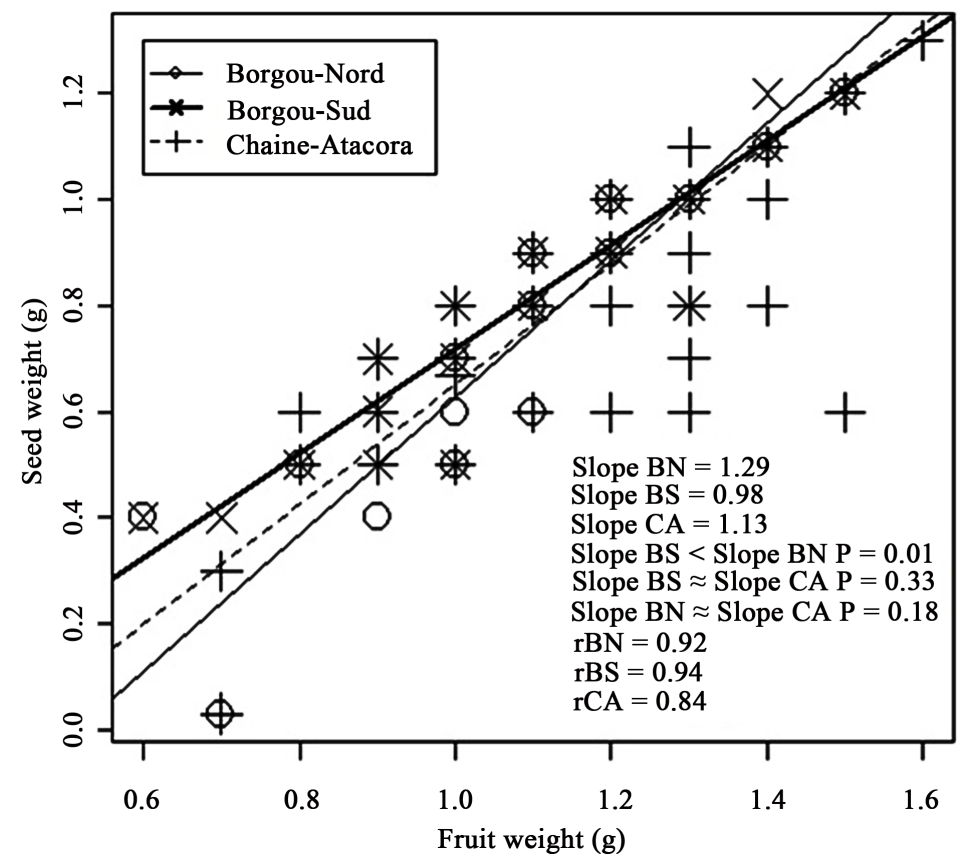

Figure 2. SMA relationship between seed weight and fruit weight of $L$. lanceolata following phytodistricts. Note: $\mathrm{BN}=$ Borgou-Nord, $\mathrm{BS}=$ Borgou-Sud, $\mathrm{CA}=$ Atacora-Chain, $\mathrm{r}=$ Pearson regression coefficient. 
these correlations have a genetic basis. Indeed, the inheritance of quantitative traits (length, diameter, weight) is generally considered polygenic [22] and a phenotypic correlation between two polygenic traits may have a genetic or environmental basis and these traits are not necessarily transmissible to the next generation [23]. Further study is needed to understand the underlying factors of the phenotypic correlation observed in L. lanceolata. However, there is no significant correlation between fruits and seeds traits and tree descriptors ( $\mathrm{dbh}$, total height) or leaves descriptors (petiole length, leaf diameter, leaf area), indicating that these cannot be used to predict the characteristics of fruits and seeds. Similar results were observed for Sclerocarya birrea subsp. birrea in Benin [9] and Burkina Faso [24], as well as for Vitellaria paradoxa in Mali [25].

On the other hand, the dbh, the total height and the petiole length are positively and significantly correlated with the number of fruits per tree. Largest and tallest trees with long petiole leaves produce more fruits. The dbh, total height and petiole length can therefore be used to predict the amount of fruit that $L$. lanceolata can produce. The results obtained are similar to those obtained by [26] according to which $\mathrm{dbh}$ and crown diameter of Lannea microcarpa are good predictors of fruit production of this species. Similarly, the dbh and the total height of Parkia biglobosa are positively correlated with the total weight of the fruits [27]. Observations made in this study showed that the smallest fruiting individual has a dbh of $7.9 \mathrm{~cm}$. At this diameter, production is low and increases gradually with diameter. These results are of interest for future studies that may focus on modeling oilseed productivity as suggested by [28].

\subsection{Relationship between Morphological Traits of $L$. Ianceolata and Functional Strategies}

Morphological traits such as limb diameter, large and small sepals' length, small sepal's width, fruit diameter fruit length, seed length, seed diameter, leaf area do not differ significantly between phytodistricts. This suggests that these traits are not affected by the climate difference at the country's phytodistricts level. However, total height, dbh, fruit weight, and fruit production differed significantly between phytodistricts. Productive trees in Borgou-Nord and Borgou-Sud are higher and larger in diameter. In the Atacora-Chain phytodistricts, producing trees have a small diameter, a low height, and produce few fruits that are generally heavier. This suggests a certain precocity of fruit production at individuals level in the Atacora Chain phytodistricts, although these differences may also be related to environmental conditions as emphasized by [29] in the case of Tamarindus indica in Uganda. In fact, the soil is mainly ferruginous on crystalline rocks in the Borgou-Nord and Borgou-Sud phytodistricts, whereas it is mainly mineral soils and little evolved in the Atacora-Chain phytodistrict with a very particular climate [21]. Habitat type and human activities could also explain the differences noted because according to [26], trees in a field are more accessible and vulnerable to intensive uses, while trees in remote plant formations are less vulnerable to intensive use by the populations. Debarking and cutting branches 
would increase the risk of infection and expose plants to predators, fire and dehydration [30], ultimately affecting fruit production. [30] noted in Burkina Faso that pruning and debarking would negatively affect fruit production of Lannea microcarpa unlike [26] showed that debarking of this same species positively affects the total number of fruits and the fruit mass in the humid Sudanian zone, suggesting that trees respond to these constraints by reassigning their resources to produce a better fruit quality (bigger and wiser). Future studies should therefore elucidate the impact of anthropogenic pressures and habitat types on the variation of morphological traits and fruit production of L. lanceolata in Benin.

\subsection{Implications for Sustainable Management and Conservation of L. lanceolata}

The existence of variability of traits between phytodistricts is essential for selection for domestication purposes [9]. In the process of domestication, this variability could provide opportunities to identify and select new cultivars through an orientated selection scheme that may involve the precocity and abundance of fruit produced. From the point of view of conserving the genetic resources of trees, intraspecific genetic variations are needed to ensure the future adaptability of the species that would occur after natural selection [22]. In Nigeria and Cameroon for example, vegetative reproduction (layering, suckering, and cuttings) of $L$. lanceolata has been undertaken due to increased interest in this species [20] [31]. In Benin, however, L. lanceolata fruits remain underutilized and local populations have not undertaken tree plantations [17]. This species should be promoted in agroforestry systems as already suggested by many studies [16] [17] [18] [20] [31]. L. lanceolata should still be considered a wild species in many agroforestry systems and additional efforts are needed to ensure its domestication. The characteristics of precocity of certain individuals and the good production of fruit in addition to their ecological adaptability and aptitude for regeneration confer to L. lanceolata a place of choice among the agroforestry woody species in Benin.

\section{Conclusion}

The present study focused on the characterization of the functional traits of $L$. lanceolata in Benin and the prediction of fruit production and morphological traits of fruits and seeds of this species based on trunk and leaf descriptors. It appears that there is a positive and significant correlation between the morphological traits of fruits and seeds suggesting that the morphological traits of the seeds can be predicted through the fruit traits. However, some morphological traits of trees (e.g., total height, dbh, and leaf petiole length) are good predictors of $L$. lanceolata fruit production but are not significantly correlated with fruit and seed traits. This study also revealed that in the phytodistrict of Atacora Chain, breeding trees have small diameter, low height, and produce few fruits that are generally heavier, contrary to the phytodistricts of Borgou-Nord and Borgou-Sud where breeding trees are higher and larger in diameter and produce 
a lot of less heavy fruits. The results could be used for the progressive domestication of this vegetable oil resource in Benin.

\section{Acknowledgements}

We are grateful for having received financial support from the International Foundation for Sciences (IFS).

\section{Conflicts of Interest}

The authors declare no conflicts of interest regarding the publication of this paper.

\section{References}

[1] Ouédraogo, A., Thiombiano, A., Hahn-Hadjali, K. and Guinko, S. (2005) Structure du peuplement juvénile et potentialités de régénération des ligneux dans l'Est du Burkina Faso. Etudes sur la flore et la végétation du Burkina Faso et des pays avoisinants. Etudes flor. vég. Burkina Faso, 10, 17-24.

[2] Tchatat, M. and Ndoye, O. (2006) Étude des produits forestiers non ligneux d'Afrique centrale: Realites et perspectives. Bois et Forêts des Tropiques, 288, 27-39.

[3] Agoyi, E.E., Assogbadjo, A.E., Gouwakinnou, G., Okou, F.A.Y. and Sinsin, B. (2014) Ethnobotanical Assessment of Moringa oleifera Lam. in Southern Benin (West Africa). Ethnobotany Research \& Applications, 12, 551-560. https://doi.org/10.17348/era.12.0.551-560

[4] Neuenschwander, P., Sinsin, B. and Goergen, G. (2011) Protection de la Nature en Afrique de l'Ouest: Une Liste Rouge pour le Bénin. Nature Conservation in West Africa: Red List for Benin. International Institute of Tropical Agriculture, Ibadan.

[5] Dicko, A., Biaou, H.S.S., Natta, A.K., Gado, C.A.S. and Kouagou, M. (2016) Influence des pressions anthropiques sur la structure des populations de Pentadesma butyracea au Bénin. VertigO-la revue électronique en Sciences de P Environnement, 16, 1-22. http://vertigo.revues.org/18195 https://doi.org/10.4000/vertigo.18195

[6] Teshome, M., Eshete, A. and Bongers, F. (2017) Uniquely Regenerating Frankincense Tree Populations in Western Ethiopia. Forest Ecology and Management, 389, 127-135. https://doi.org/10.1016/j.foreco.2016.12.033

[7] Ouinsavi, C. and Sokpon, N. (2010) Morphological Variation and Ecological Structure of Iroko (Milicia excelsa Welw. C.C. Berg) Populations across Different Biogeographical Zones in Benin. International Journal of Forestry Research, 2010, Article ID: 658396. https://doi.org/10.1155/2010/658396

[8] Houètchégnon, T., Gbèmavo, D.S.J.C., Ouinsavi, C.A.I.N. and Sokpon, N. (2015) Morphological Variability of Prosopis africana (Guill., Perrott. and Rich.) Taub in Benin, West Africa. American Journal of Plant Sciences, 6, 1069-1079. https://doi.org/10.4236/ajps.2015.67111

[9] Gouwakinnou, G.N., Assogbadjo, A.E., Lykke, A.M. and Sinsin, B. (2011) Phenotypic Variations in Fruits and Selection Potential in Sclerocarya birrea subsp. Birrea. Scientia Horticulturae, 129, 777-783. https://doi.org/10.1016/j.scienta.2011.05.041

[10] Soloviev, P., Niang, T. and Gaye, A. (2004) Propagation par greffage du prunier d'Afrique [Sclerocarya birrea (A. Rich) Hochst.]. Au Sénégal. Fruits, 59, 275-280. https://doi.org/10.1051/fruits:2004026 
[11] Atefe, K., Kambiz, T.A. and Javad, T. (2015) Variations in Leaf and Fruit Morphological Traits of Sweet Chestnut (Castanea Sativa) in Hyrcanian Forests, Iran. International Journal of Plant Science and Ecology, 1, 155-161.

[12] Glèlè Kakaï, R., Akpona, T.J.D., Assogbadjo, A.E., Gaoué, O.G., Chakeredza, S., Gnanglé, P.C., Mensah, G.A. and Sinsin, B. (2011) Ecological Adaptation of the Shea Butter Tree (Vitellaria paradoxa C.F. Gaertn.) along Climatic Gradient in Bénin, West Africa. African Journal of Ecology, 49, 440-449. https://doi.org/10.1111/j.1365-2028.2011.01279.x

[13] Freigoun, S.A.B., Raddad, E.Y.A. and Elagib, T.Y. (2017) Provenance Variation in Seed Morphological Traits and Early Seedling Growth of Balanites aegyptiaca Del. Sudan Journal of Agricultural Research, 27, 93-108.

[14] Samim, S., Sood, S., Singh, A., Verma, A. and Kaur, A. (2018) Morphological Characterization of Okra [Abelmoschus esculentus (L.) Moench]. International Journal of Current Microbiology and Applied Sciences, 7, 2011-2019. https://doi.org/10.20546/ijcmas.2018.710.232

[15] Dao, M.C.E., Diallo, B.O. and Kabore-Zoungrana, C. (2012) Fruit and Seed Production in a Natural Population of a Dioecious Plant: Piliostigma reticulatum HOSCHT (Caesalpinioïdeae). International Journal of Biological and Chemical Sciences, 6, 11-23. https://doi.org/10.4314/ijbcs.v6i1.2

[16] Dossa, A.D. (2011) Structures et dynamiques des populations rémanentes de Lophira lanceolata Tiegh. ex Keaydans le département de l'Atacora au Nord-Ouest du Bénin, Mémoire de DESS en Aménagement et Gestion Durable des Ressources Naturelles. EDP, Université de Parakou, Bénin.

[17] Dicko, A., Natta, A.K. and Biaou, H.S. (2017a) Connaissances ethnobotaniques et conservation de Lophira lanceolata (Ochnaceae) au Bénin (Afrique de l'ouest). Annales des Sciences Agronomiques, 21, 19-35.

[18] Kouaro, O.M. and Tasso, F. (2010) Lophira lanceolata dans la Commune de Toucountouna: Entre exploitation et conservation d'une espèce naturelle à usages multiples. Revue de géographie du Bénin, 7, 94-115.

[19] Nonviho, G. (2015) Valorisation chimique de la biomasse oléagineuse d'origine béninoise: Lophira lanceolata et Carapa procera. Thèse de doctorat en cotutelle, Université d'Abomey-Calavi, Bénin \& Université de Lorraine, Bénin.

[20] Mapongmetsem, P.M. (2007) Lophira lanceolata Tiegh. ex Keay. In: van der Vossen H.A.M. and Mkamilo, G.S., Eds., PROTA 14. Vegetable Oils/Oléagineux, PROTA, Wageningen, 115-118.

[21] Adomou, A.C., Sinsin, B. and van der Maesen, L.J.G. (2006) Phytosociological and Chorological Approaches to Phytogeography: A Meso-Scale Study in Benin. Systematics and Geography of Plants, 76, 155-178.

[22] Allendorf, F.W. and Luikart, G. (2007) Conservation and the Genetics of Populations. Blackwell Publishing, Oxford.

[23] White, T.L., Adams, W.T. and Neale, D.B. (2007) Forest Genetics. CAB International, Oxfordshire. https://doi.org/10.1079/9781845932855.0000

[24] Bationo, P., Zongo, J.D., Nanéma, K.R. and Traoré, R.E. (2008) Étude de la variation de quelques caractères morphologiques d'un échantillon de Sclerocarya birrea au Burkina Faso. International Journal of Biological and Chemical Sciences, 4, 549-562.

[25] Sanou, H., Picard, N., Lovett, P.N., Dembélé, M., Korbo, A., Diarisso, D. and Bouvet, J.-M. (2006) Phenotypic Variation of Agromorphological Traits of the Shea Tree, Vitellaria paradoxa CF Gaertn., in Mali. Genetic Resources and Crop Evolution, 53, 145-161. https://doi.org/10.1007/s10722-004-1809-9 
[26] Goudegnon, E.O.A., Gouwakinnou, G.N., Houessou, L.G. and Oumorou, M. (2016) Fruit and Pulp Production of the African Grape Lannea microcarpa Engl. \& K. Krause from Dry and Humid Sudanian Zone in Northern Bénin, West Africa. International Journal of Biological and Chemical Sciences, 10, 1114-1121. https://doi.org/10.4314/ijbcs.v10i3.17

[27] Gbedji, E.K.Y. (2003) Caractérisation morphologique et structurale des parcs à Néré (Parkia biglobosa (Jack;) R.Br. Ex. G. Dom.) au Bénin. Thèse d'Ingénieur Agronome, Faculté des Sciences Agronomiques (FSA), Université d'Abomey-Calavi (UAC), Bénin.

[28] Lamien, N., Tigabu, M., Guinko, S. and Oden, P.C. (2006) Variations in Dendrometric and Fruiting Characters of Vitellaria paradoxa Populations and Multivariate Models for Estimation of Fruit Yield. Agroforestry Systems, 69, 1-11. https://doi.org/10.1007/s10457-006-9013-x

[29] Okello, J., Okullo, J.B.L., Eilu, G., Nyeko, P. and Oboe, J. (2018) Morphological Variations in Tamarindus indica Linn. Fruits and Seed Traits in the Different Agroecological Zones of Uganda. International Journal of Ecology, 2018, Article ID: 8469156. https://doi.org/10.1155/2018/8469156

[30] Haarmeyer, D.H., Schumann, K., Bernhardt-Römermann, M., Wittig, R., Thiombiano, A. and Hahn, K. (2013) Human Impact on Population Structure and Fruit Production of the Socio-Economically Important Tree Lannea microcarpa in Burkina Faso. Agroforestry Systems, 87, 1363-1375.

https://doi.org/10.1007/s10457-013-9644-7

[31] Fawa, G., Mapongmetsem, P.M., Tchingsabe, O., Doumara, D., Nenbe, N. and Dona, A. (2014) Root Suckering of Lophira lanceolata Tiegh. ex Keay (Ochnaceae) in the Guinean Savannah Highlands of Cameroon. International Research Journal of Plant Science, 5, 30-36. 